\title{
Promoting Harmonisation Across the European Patent System Through Judicial Dialogue and Cooperation
}

\author{
Karen Walsh (D)
}

Published online: 11 April 2019

(C) The Author(s) 2019

\begin{abstract}
In order to promote harmonisation in a more effective manner in the European patent system, it is argued that this should not solely be done through legislation, but through judicial dialogue and cooperation. Through this means of informal harmonisation, progress can be made case-by-case, rather than waiting for legislation to be agreed upon and entered into force. This is already happening to good effect, as displayed through a number of examples, including the most recent example of Actavis v. Eli Lilly [2017] UKSC 48 in the UK Supreme Court. It is proposed by this article that official lines of communication should be opened among all judiciaries and Boards in the European patent system to improve this practice. Judicial cooperation would also be useful to the Unified Patent Court, if it becomes operational. Opening official lines of communication would be an important step towards a further harmonised European patent system and would increase legal certainty in this area.
\end{abstract}

Keywords European patent law $\cdot$ Patent claim construction · Doctrine of equivalents · Actavis v. Eli Lilly · Harmonisation · Judicial cooperation and dialogue

\section{Introduction}

There have been many attempts to introduce a unitary patent system in Europe, in order to promote harmonisation, yet none have been successful thus far. The

Karen Walsh would like to thank Dr Naomi Hawkins, Professor Andrea Lista, Dr Aisling McMahon, and Alexandra Mogyoros for their comments on earlier drafts of this paper, Dr Justine Pila for her support and insight, and the anonymous reviewers for their feedback. A version of this paper was presented at the SCuLE IP Work in Progress Seminar and the author is grateful to those who participated in the resulting discussion. This study did not generate any new data.

K. Walsh $(\bowtie)$

DPhil (Oxford); Lecturer, University of Exeter, Exeter, UK

e-mail: k.walsh@exeter.ac.uk 
currently proposed unitary patent system for European Union (EU) Member States has faced many difficulties but is the closest that the EU has come to having a unitary system. However, when discussing the European patent system, consideration must also be given to those countries outside the EU, but within Europe. ${ }^{1}$ If the currently proposed system enters into force, it will add another layer onto the already multi-faceted patent system both before and after grant.

One of the main concerns with the current patent systems that exist in Europe is the lack of cross-border enforcement of decisions when it comes to validity, and usually infringement (given that validity is often raised as a counterclaim in infringement actions). When a case on the same patented invention comes before different national courts, divergent decisions can and have arisen. ${ }^{2}$

Unitary systems propose to reduce the occurrence of this divergence. However, since all of these proposals have so far failed and are also mostly relevant to EU Member States only, it is necessary to investigate an alternative means of promoting harmonisation across the entire European patent system. ${ }^{3}$

It is important to assess how harmonisation can be promoted and achieved in the European patent system with or without a unitary system in place. This is especially significant in the current climate given the precarious footing on which the currently proposed unitary patent system finds itself. This article investigates an alternative and proposes that the most effective means of promoting harmonisation throughout the entire European patent system is judicial dialogue and cooperation. ${ }^{4}$

The paper commences by examining and highlighting the shortcomings of existing approaches to harmonisation in the EU and broader European (EPC) context, namely, attempts by the EU and EPC to legislate in this area to promote harmonisation, with a specific focus on patent claim interpretation and the matter of equivalents. This paper argues that legislating in this area is first difficult to reach a compromise on, second, takes a long time to enter into force, and third, does not always have the intended outcome.

It will then set out an alternative way forward by developing a novel argument for why there needs to be a shift in thinking about how to secure harmonisation in this context. It does so by examining in detail a means for harmonisation without legislation, which also maintains room for national diversity - that is, informal, yet effective, harmonisation by encouraging judicial dialogue and cooperation.

\footnotetext{
${ }^{1}$ Those countries are: Albania, Iceland, Liechtenstein, Former Yugoslav Republic of Macedonia, Monaco, Norway, San Marino, Serbia, Switzerland, Turkey.

${ }^{2}$ Graham and Van Zeebroeck (2014), pp. 655, 708. This evidence has been confirmed in another more recent study published in 2016: Cremers et al. (2016).

${ }^{3}$ In this article, when referring to the European patent system this does not refer to a specific patent system and includes both EU and non-EU countries; when referring to the European (European Patent Convention EPC) patent system, this includes the Contracting States to the EPC and refers to the system implemented by the EPC; and when referring to the proposed unitary patent system, this refers to the system that may be introduced by the unitary patent package and includes participating EU Member states only.

${ }^{4}$ When speaking of "judicial" dialogue, for the purpose of this article this will include national court judges, judges from the Court of Justice of the European Union, and members of the Boards of Appeal of the European Patent Office. Although the Boards of Appeal are quasi-judicial, they do exercise similar functions (albeit in the patent context) and act in the same spirit.
} 
By taking judgments on patent law from other jurisdictions into account, practices will further align, but it will not be required in areas wherein countries disagree fundamentally. It is found that this is already occurring, but it is argued in this paper, for the first time, that official lines of communication should be set-up between the institutions of the European patent system to ensure that the informal harmonisation that is already happening will continue to occur and become more prevalent. In turn, this will lead to stronger legal certainty in the European patent system.

A recent case, Actavis v. Eli Lilly [2017] UKSC 48, is then analysed and used as an example of how judicial cooperation works at its best. Decades of precedent was significantly changed by the Supreme Court when a doctrine of equivalents was introduced into United Kingdom (UK) law, aligning practice with its European neighbours.

The UK context is being used as the main example throughout this piece owing to its prominence in the European patent system and attitude towards judicial harmonisation. There is also reference to Germany, as well as France and the Netherlands (to a lesser extent), given the high levels of patent law activity in these jurisdictions. However, the arguments made can apply to other European countries.

The argument herein can also be taken further if the proposed unitary patent system does enter into force. In that instance, the Unified Patent Court (UPC) can participate in judicial dialogue and cooperation with the currently existing institutions.

\section{The Harmonisation Agenda}

Harmonisation has long been an ambition for the European patent system given the numerous benefits with which it can bring. One of the main benefits of a harmonised system, is increased legal certainty for all parties involved, including the public. ${ }^{5}$

In a harmonised system, pre-grant search and examination is the same for all countries. As a result, patent applicants will know that their invention is patentable or non-patentable across the jurisdiction and thus could predict its commercial success. This would also be of benefit to third parties who are either trying to avoid infringement or compete with the patent owner.

Post-grant, a harmonised system would ensure that decisions on patented inventions across the jurisdiction are mostly decided in the same way and the same result is achieved. For third parties, this brings the certainty that if they are found non-infringing in one country, the same would happen in others.

Overall, a harmonised system is also generally less costly than individual systems. Translation requirements are not as burdensome and renewal costs are usually lower than individual systems. This would certainly be of benefit to patent applicants and would also improve European competitiveness in an increasingly international area.

\footnotetext{
5 For more on harmonisation, see Van Pottelsberghe (2009).
} 


\subsection{Setting the Scene}

To date, there have been numerous legislative attempts at unifying and harmonising the European patent system with a number of major achievements. These attempts date back to 1949, when French Senator, Henri Longchambon, proposed a type of unitary patent system for Europe.

The first major achievement regarding harmonisation in the field was by the Council of Europe. Its aim was the unification of the patent system; however, it was believed that this could not be achieved before the harmonisation of substantive patent law matters. ${ }^{6}$ Therefore, the Strasbourg Patent Convention 1963 essentially harmonised the substantive patent law requirements for all Contracting States. ${ }^{7}$ Despite these requirements being implemented into national laws, their interpretation can differ.

The second major achievement was introduced following proposals for a unitary patent system from the European Economic Community (EEC) and the European Free Trade Association (EFTA). ${ }^{8}$ The proposals put forward culminated in a twopronged approach. ${ }^{9}$ The first was the EPC 1973, which was successfully ratified and entered into force in $1977 .{ }^{10}$ The main aim of the EPC was and is to stream-line the procedure for the grant of patents in Europe. The second was the Community Patent Convention 1975 (CPC), which twice failed to gather the necessary ratification to enter into force. ${ }^{11}$ The main aim of the CPC was to introduce a unitary patent for the Member States of the EEC.

The EPC currently applies to 38 Contracting States, including all EU Member States. Its provisions have been implemented into the national laws of all Contracting States. It introduced a highly successful procedure for the grant of patents in Europe, the result of which is a bundle of national patents. Although the CPC never entered into force, many of its provisions were also implemented into national laws in preparation. These include provisions on infringement and enforcement. However, despite their implementation they remain subject to interpretation at national level, where differences can arise and have arisen. ${ }^{12}$

As there are a number of routes to patent protection available (national/EPC), none so far being unitary, a decision is required each time an application is made, and this can lead to different results in both grant and enforcement.

\footnotetext{
${ }^{6}$ Wadlow (2010), pp. 123, 126.

${ }^{7}$ Convention on the Unification of Certain Points of Substantive Law on Patents for Invention 1963 (Strasbourg Patent Convention); For a detailed analysis of the Convention, see Wadlow (2010).

${ }^{8}$ Pila (2013), pp. 917, 926.

9 Pila (2013), p. 926; citing Ladas (1975), p. 633.

${ }^{10}$ Convention on the Grant of European Patents of 5 October 1973 (European Patent Convention) (EPC).

${ }^{11}$ Convention for the European Patent for the Common Market (15 December 1975) (Community Patent Convention) (CPC); re-enacted as Council Agreement 89/695/EEC of 15 December 1989 relating to Community Patents [1989] OJ L 401/1.

12 The most famous example being Improver v. Remington: UK - Improver Corp v. Remington Consumer Product Ltd [1990] F.S.R 181; Germany - Improver Corp. \& Sicommerce AG v. Remington Products Inc, Case No. 2 U 27/89 (OLG 1991) translated in 24 IIC p. 838 (1993); the Netherlands translated in 24 IIC p. 832 (1993).
} 
If a patent applicant chooses to apply for protection via the national patent systems, this could result in a patent being granted in some countries and not others. Reasons for this include differing standards of search and examination or morality issues for example.

An application through the European (EPC) patent system ensures a standard level of search and examination. In usual circumstances, once a patent is granted by the EPO, national offices will validate that patent automatically or on request. However, there are some areas in which Contracting States have differing views to the EPO on how the requirements of patentability ought to be determined. Whether there would be a difference in the overall result at different offices is arguable, but possible. The main concern regarding harmonisation pre-grant is whether the claims of the patent will be accepted in all jurisdictions.

One of the most concerning difficulties with patent claims arises post-grant. In patent law practice, the claims are one of, if not the most important aspect of a patent specification.

In the national patent systems, matters of validity and infringement are dealt with by the respective national courts. If a case concerning the same patented invention comes to different national courts, those courts could reach and have reached different decisions.

In the European (EPC) patent system, the EPO deals with any opposition actions made within nine months of grant. ${ }^{13}$ The European patent can only be centrally revoked by a successful opposition procedure. Following this nine-month period, any action related to a patent will be brought to the relevant national court. It is after this point that divergence can occur. ${ }^{14}$

Once an action is brought before any national court, the claims of the patent must be interpreted in order to determine the scope of protection of the patent. This is where the divergence often occurs - whether or not an alleged infringing article falls within the scope of protection of the patented invention.

Since the failure of the CPC, attempt after attempt has been made to introduce a unitary patent system to rectify this issue. ${ }^{15}$ The current attempt, the unitary patent package ${ }^{16}$ is the closest the EU has ever come to a unitary patent system. However, this proposed system has faced criticism after criticism, ${ }^{17}$ and issue after issue. ${ }^{18}$

\footnotetext{
13 Article 99 EPC.

14 This has happened in a number of cases, which will be discussed below - the most famous example is the Improver $v$. Remington case.

15 For a detailed analysis on the history of the UPC, see Wadlow (2013).

16 The package consists of: Council Regulation (EU) 1257/2012 of the European Parliament and of the Council of 17 December 2012 implementing enhanced cooperation in the area of the creation of unitary patent protection [2012] OJ L 361/1; Council Regulation (EU) 1260/2012 of the European Parliament and of the Council of 17 December 2012 implementing enhanced cooperation in the area of the creation of unitary patent protection with regard to the applicable translation arrangements [2012] OJ L 361/89; and Council Agreement 2013/C on a Unified Patent Court [2013] OJ L 175/01 (UPCA).

17 For a summary of the main critiques, see Hilty et al. (2012).

18 Although the UK have ratified the UPCA, following Brexit questions remain regarding UK involvement in the proposed system. A case has been brought before the German Constitutional Court challenging the constitutionality of the German ratification legislation. The Hungarian Constitutional Court decided that there is no mechanism in place for the Agreement to be ratified in Hungary.
} 
No attempt at a unitary system has so far been successful. It is therefore necessary to reassess how harmonisation can be achieved in the European patent system with or without such a system in place.

\subsection{Legislative Harmonisation in the EU}

Although the European patent system concerns countries outside the EU, the EU's attempts at unifying and harmonising the system through legislation have had an effect on the system overall. It is therefore important to trace the development of the European patent system within the EU agenda.

Since the regulation of European patent law was taken over by the EEC from the Council of Europe, patent law has been an integral part of the harmonisation agenda of the EU and the functioning of the internal market. How harmonisation can be achieved through legislation has changed over time. The introduction of mechanisms, such as enhanced cooperation, has allowed for the possibility of harmonisation in certain Member States, without the agreement of all Member States. This type of process is arguably one of the ways forward for harmonisation, a way which allows for harmonisation but not at the expense of national diversity.

Due to the limitations of law making in the EU generally - namely, the difficulty of coming to a compromise, or the extent of compromise it takes to reach agreement between a generally expanding number of Member States - it was clear that a change was necessary in how harmonisation could be achieved. With the continued expansion of the EU, in both geographical and legal terms, the methods used to achieve harmonisation had to modernise.

This was foreseen as early as 1992, with the entry into force of the Treaty on the European Union (TEU). The TEU introduced mechanisms such as "closer cooperation" between some Member States under Title VI, Provisions on Cooperation in the Fields of Justice and Home Affairs. ${ }^{19}$ The TEU was extensively criticised at the time for introducing this type of mechanism, which would apparently threaten the cohesiveness and unity of the Community order. ${ }^{20}$ To only bring some Member States closer together was not something that represented integration at the time.

Regardless, further amendments made by the Treaty of Amsterdam 1997 brought the mechanism of closer cooperation into new realms and made it easier for Member States to use. Title VIa was introduced which provided for Provisions on Closer Cooperation, which was much more inclusive than the previous provision in the TEU 1992. Article K.15 Treaty of Amsterdam 1997 provides that:

1. Member States which intend to establish closer cooperation between themselves may make use of the institutions, procedures and mechanisms laid down by this Treaty and the Treaty establishing the European Community provided that the cooperation:

\footnotetext{
19 Article K.7 TEU. Closer cooperation was a precursor to enhanced cooperation.

${ }^{20}$ Curtin (1993), pp. 17-67.
} 
(a) is aimed at furthering the objectives of the Union...

(b) respects the principles of the said Treaties...

(c) is only used as a last resort, where the objectives of the said Treaties could not be attained by applying the relevant procedures...

(d) concerns at least a majority of Member States;

(e) does not affect the acquis communautaire...

(f) does not affect the competences, rights, obligations and interests of these Member States which do not participate...

(g) is open to all Member States and allows them to become parties to the cooperation at any time, provided that they comply with the basic decision and with the decisions taken within that framework;...

This provision was the first to provide extensive guidance on the mechanism that is known today as enhanced cooperation. ${ }^{21}$ These guidelines formed the basis of that procedure which allows a number of Member States to move forward with initiatives that would promote the harmonisation of the Union without needing the agreement or participation of all Member States. This procedure also leaves open the possibility for all Member States to join the cooperation in question at a later date, so far as it complies with what is set out in that agreement. The procedure has only been successfully used once so far. ${ }^{22}$ However, its use for the proposed European unitary patent system has drawn more attention to it, and subsequently to the concept of differentiated integration.

Differentiated integration is a concept that goes alongside the procedure of enhanced cooperation. Rather than forcing the currently 28 Member States to compromise on legislation, which can sometimes result in essentially nothing, differentiated integration provides an alternative. It allows Member States that do agree to harmonise certain areas without having to lose the essence of the proposed legislative changes to compromise.

Some commentators have even gone so far as to suggest that "differentiated integration is no longer an option, but a necessary condition of progress". ${ }^{23}$ Although this is an exceptional stance, the argument behind it has merit. Due to the reasons outlined above with regard to difficulties in law making, a change is needed. Differentiated integration could be that change. Progress can be made on harmonisation even without all Member States participating. The remaining hope is that those Member States who are unwilling or unable to join the cooperation at the time, will do so in future, thus potentially using differentiated integration as a method to achieve "true" EU integration.

This concept also allows for harmonisation without requiring a Member State to give up a further portion of its sovereignty when it does not agree with the position being taken. Therefore, harmonisation in this way can be achieved without hindering national diversity.

\footnotetext{
21 Now contained in Art. 20(2) TEU.

22 Council Regulation (EU) No 1259/2010 of 20 December 2010 implementing enhanced cooperation in the area of the law applicable to divorce and legal separation.

23 Majone (2008), p. 457.
} 
This was a key factor in the current proposals for the harmonisation of the European patent system in the unitary patent context. Spain refused to agree to the terms of the Regulations due to the language regime contained therein. It was argued that either Spanish and Italian should be added to the current language regime, or, that English alone ought to be the official language of the proposed European unitary patent system. ${ }^{24}$ Spain were, and remain, unwilling to sign up to the unitary patent system as it currently stands and therefore, the enhanced cooperation procedure had to be used in order to move forward. ${ }^{25}$

However, as evidenced by the unitary patent package, law making in the field of patents, even by enhanced cooperation, can take a very long time. The current iteration has been awaiting entry into force since 2013 and was debated on and off from 2000 to 2013. It was only with the mechanism of enhanced cooperation that it could move forward, so although the introduction of mechanisms of differentiated integration have assisted, the legislative process still takes a long time, and the end is not yet in sight.

Furthermore, the proposed system is currently on a precarious footing, mainly due to Brexit and an issue before the German Constitutional Court. ${ }^{26}$ For the proposed system to enter into force, the UPCA must be ratified by 13 EU Member States, including France, Germany and the UK. ${ }^{27}$

Despite Brexit, the UK has ratified the Agreement. However, a question remains as to whether the UK could or would continue to participate in the unitary patent system after leaving the EU given that the unitary patent system is for participating EU Member States. ${ }^{28}$ If the UK does not participate in the system post-Brexit, the system itself becomes a lot less beneficial to the parties involved.

Ratification in Germany has been stalled by a case that has been brought to the German Constitutional Court regarding the constitutionality of the proposed system. The complainant contends that the necessary qualified majority was not achieved when voted on in Parliament and that the Agreement is not compatible with EU law. ${ }^{29}$ It is expected that the case will be heard in 2019. If it is not dismissed, the proposed system will face even more problems before entry into force.

Even if these issues are laid to rest and the proposed unitary patent system enters into force, problems remain that will keep the system on shaky ground. First, it does

\footnotetext{
24 Council Document (EU) 13031/10 of 31 August 2010 on Reflection from the Spanish delegation on a possible model for the Regulation on translations [2010] LIMITE PI 94.

25 Italy had also taken this position, but has since implemented the Regulations and ratified the Agreement.

26 A complaint (2 BvR 739/17) made to the German Constitutional Court will apparently be decided upon in 2019, as evidenced by the Court's list of cases at: https://www.bundesverfassungsgericht.de/EN/ Verfahren/Jahresvorausschau/vs_2019/vorausschau_2019_node.html last accessed 25 February 2019.

27 France, the UK, and 14 other Member States have ratified the Agreement.

28 Although this is legally possible, the question remains as to whether it is politically possible. For a legal analysis, see Gordon and Pascoe (2016); Ohly and Streinz (2017), p. 245; Sellens (2018), p. 136; McMahon (2018), p. 175; and Walsh (2019).

29 A number of views have been published on this issue. See for example: "EPLIT, BRAK, GRUR publish view on German complaint against ratification UPCA" (Kluwer Patent Blog, 25 January 2018) available at: http://patentblog.kluweriplaw.com/2018/01/25/eplit-brak-grur-publish-view-germancomplaint-upca-ratification/ accessed 20 August 2018.
} 
not include all EU Member States, let alone all European countries; second, whether or not the UK remains in the proposed unitary patent system post-Brexit is questionable; and third, the new system would not replace any of the current systems. These problems all leave gaps in the legislature's quest for a harmonised patent system in Europe. Therefore, it is even more important to ensure that other avenues for harmonisation are investigated, because with or without the entry into force of a unitary patent system, problems remain.

\subsection{Legislative Harmonisation Outside the EU - the Protocol on Interpretation of Art. 69 EPC: the EPCs Legislative Attempts to Harmonise Patent Claim Interpretation}

As well as the EU legislating via enhanced cooperation, harmonisation in the European patent system has also been encouraged outside the EU by the legislative provisions of the EPC. This attempt is especially important given that the European patent system contains more than EU Member States. In this section there will be a focus on patent claim construction, as this is one of few areas where harmonisation was attempted through provisions of the EPC and an additional Protocol. ${ }^{30}$

\subsubsection{Pre-EPC}

Prior to the implementation of the EPC, countries in Europe had different methods of claim construction. There were two ends of the interpretative spectrum - a strict literal approach and a sign-post approach.

Originally in the UK, a strict literal interpretation of the text of the claims was used. This involved viewing the claims of the patent application as the definition of the invention - whatever was claimed was within the scope of protection of the patent and whatever was not claimed was outside the scope of protection. This was the case even if the difference between the claimed invention and the alleged infringing product was insignificant to the functioning of the invention.

The issue was that minor changes could be made to a protected invention and that competing product could be placed on the market without amounting to an infringement. Therefore, the UK courts began to implement a new method of interpretation - the pith and marrow approach. ${ }^{31}$

Here, the courts would determine the "essential feature" of the claimed invention. If the alleged invention took the essential feature or "pith and marrow" of the patented invention, that would constitute an infringement. However, it was questioned from whose perspective the "essential features" of the invention should be determined. That problem came into focus in Catnic $v$. Hill \& Smith, which was decided before the EPC became law in the UK. ${ }^{32}$

\footnotetext{
30 The provisions of Council Directive 98/44/EC of the European Parliament and of the Council of 6 July 1998 on the legal protection of biotechnological inventions [1998] OJ L 213/13 (Biotech Directive) were also implemented into the Implementing regulations of the EPC (Chapter V, Rule 26(1) Implementing Regulations to the EPC 2000) to ensure that patents on biotech inventions were treated the same across Europe.

31 First mentioned in a dissenting opinion by Lord Reid in Van der Lely v. Bamfords [1963] RPC 61.

32 Catnic v. Hill \& Smith Limited [1982] RPC 183.
} 
The invention concerned steel lintels, whose rear member, in the Catnic patent application, was "extending vertically". 33 The Hill \& Smith invention concerned a very similar product, however, the rear member "inclined $6^{\circ}$ or $8^{\circ}$ from the vertical". ${ }^{34}$ At first instance, Whitford J held that although there had been no "textual infringement" of the claims, Hill \& Smith "had taken all the essential features of a number of claims" and that was held to be an infringement. $^{35}$

The case went to the Court of Appeal, wherein it was held that the "essential feature" of the invention was that the rear members extended vertically and thus, there was no infringement. ${ }^{36}$ The issue of patent infringement reached the House of Lords where it was stated by Lord Diplock that "a patent specification should be given a purposive construction rather than a purely literal one". 37

The House of Lords decided that patent claims ought to be viewed from the perspective of the person skilled in the art who should examine the claims from the perspective of the patentee and take into account their intention. The scope of protection was therefore dependant on the intention of the patentee, striking what was seen as a fairer balance between the interests of parties involved.

Germany was at the other end of the interpretative spectrum. Originally a signpost approach was used, the claims only serving as a guideline to the scope of protection. More important in German claim construction was the "direct subject matter" of the invention, the "technical teaching" of the invention, and also the "general inventive idea". ${ }^{38}$ The actual wording of the claims was far less important, which was strikingly different to the literal approach, and a lot more flexible. In comparison to the purposive approach (the early stages of which were seen in Catnic), the sign-post approach was still significantly different, owing to its lack of focus on the wording of the claims.

The differences in these interpretative approaches was an issue because by having such differences, contrasting decisions were more likely to emerge on cases to do with the same patented invention. That issue became even more significant on the entry into force of the EPC.

\subsubsection{Enter the EPC}

Following the entry into force of the EPC, Contracting Member States had to comply with Art. 69 EPC, which states: "(1) The extent of the protection conferred by a European patent or a European patent application shall be determined by the claims. Nevertheless, the description and drawings shall be used to interpret the claims."

\footnotetext{
33 Catnic [1982] RPC 183, 185.

34 In fact, a previous design that Hill \& Smith had taken all the features of the Catnic invention. They had intended to manufacture this product until they received a writ for infringement from Catnic.

35 Catnic v. Hill \& Smith Limited [1978] FSR 405.

36 Catnic v. Hill \& Smith Limited [1979] FSR 619 (CA).

37 Catnic [1982] RPC 183, 243.

38 Fisher (2008), pp. 133, 148.
} 
A Protocol on the Interpretation of Art. 69 EPC was also introduced in an attempt to bring Contracting States closer together in how patent claims were interpreted. It therefore requires Contracting States to use similar methods of interpretation:

Article 69 should not be interpreted in the sense that the extent of the protection conferred by a European patent is to be understood as that defined by the strict, literal meaning of the wording used in the claims, the description and drawings being employed only for the purpose of resolving an ambiguity found in the claims. Neither should it be interpreted in the sense that the claims serve only as a guideline and that the actual protection conferred may extend to what, from a consideration of the description and the drawings by a person skilled in the art, the patentee has contemplated. On the contrary, it is to be interpreted as defining a position between these extremes which combines a fair protection for the patentee with a reasonable degree of certainty for third parties. ${ }^{39}$

In 2000, in a further attempt to harmonise patent claim interpretation, the wording of the Protocol on the Interpretation of Art. 69 EPC was amended slightly, and a second article was added. ${ }^{40}$ The original Article remains essentially the same, and the new Art. 2 states: "For the purpose of determining the extent of protection conferred by a European patent, due account shall be taken of any element which is equivalent to an element specified in the claims."

The Protocol was and remains extremely vague, however, its inclusion is important. This is especially so because the EPC is a convention that is primarily for the grant of patents, not their enforcement. These legislative provisions were the EPC's attempt to harmonise a quite divergent area and the results were variable.

\subsubsection{Changes Introduced by the EPC}

The Patents Act (UK) 1977 implemented the provisions of the EPC into national law in the UK. Therefore, the judiciary became obligated to take the provisions of the EPC into account. This is highlighted by Sec. 130(7) of the Patents Act 1977, which states that certain provisions of the Patent Act are "framed as to have, as nearly as practicable, the same effects in the UK as the corresponding provisions of the European Patent Convention".

As mentioned, Catnic was decided before the EPC became law in the UK. The next case regarding patent claim interpretation that came before the House of Lords was Improver v. Remington. ${ }^{41}$ Here, the House of Lords took the opportunity to decide on patent claim construction under the new law. In doing so, Lord Hoffman stated that a purposive approach towards claim construction ought to be taken and formulated three questions that the court could ask when dealing with patent infringement and variants.

\footnotetext{
39 Wording of the 1973 Convention.

40 Protocol on the Interpretation of Art. 69 EPC of 5 October 1973 as revised by the Act revising the EPC of 29 November 2000.

41 Improver Corp v. Remington Consumer Product Ltd [1990] FSR 181.
} 
First, it is asked whether the change makes a difference to the functioning of the invention. ${ }^{42}$ Then, it is asked whether that would have been obvious to the person skilled in the art at the date of publication. ${ }^{43}$ Finally, the perspective of the patentee is taken into account, where it is asked whether the person skilled in the art would have thought that the patentee intended that a strict reading was an essential requirement of the invention. ${ }^{44}$ These questions maintain the approach that had been taken in Catnic regarding claim construction.

The Improver questions became the go-to questions for any case to do with variants and infringement over the next 15 years in the UK. In subsequent cases, they became known as the "Protocol Questions". ${ }^{45}$ However, how they were being used was a cause for concern to Lord Hoffman, who took the opportunity to clarify matters in Kirin-Amgen v. Hoescht Marion. ${ }^{46}$

In Kirin-Amgen, Lord Hoffman explained that the Protocol Questions were to be used as guidelines and not blindly because in certain instances it would be very difficult to apply the questions to the facts of the case. ${ }^{47}$ Since that judgment, the courts in the UK showed reluctance in applying the Protocol questions and instead followed the guidance of Lord Hoffman in Kirin-Amgen. For 15 years this practice progressed, with courts and practitioners becoming familiar with the approach taken.

This was not the only issue that caused controversy with regard to claim construction. As mentioned, in 2000, an amendment was made to the EPC that had a follow-on impact in the UK. Article 2 of the Protocol on the Interpretation of Art. 69 EPC was introduced, which required that due account shall be taken of equivalents.

The issue of equivalents was discussed in the Improver case as there was an equivalents clause in the description of the patent application in suit. However, the point was given extensive consideration in Kirin-Amgen. Lord Hoffman discussed the doctrine of equivalents as it exists in other countries and made it very clear that the UK had no such doctrine. He was of the opinion that a doctrine of equivalents allows the patentee to extend their protection beyond the claims to something that "performs substantially the same function in substantially the same way to obtain the same result" as the invention. ${ }^{48}$

Lord Hoffman said that the problem lay in that once the protection expanded outside the claims, question arises as to where the line is to be drawn with variants. ${ }^{49}$ To avoid the issue of non-infringing immaterial variations, he favoured an approach that abandoned literalism in construction, rather than the introduction of a doctrine of equivalents. ${ }^{50}$ His view was that by introducing the purposive

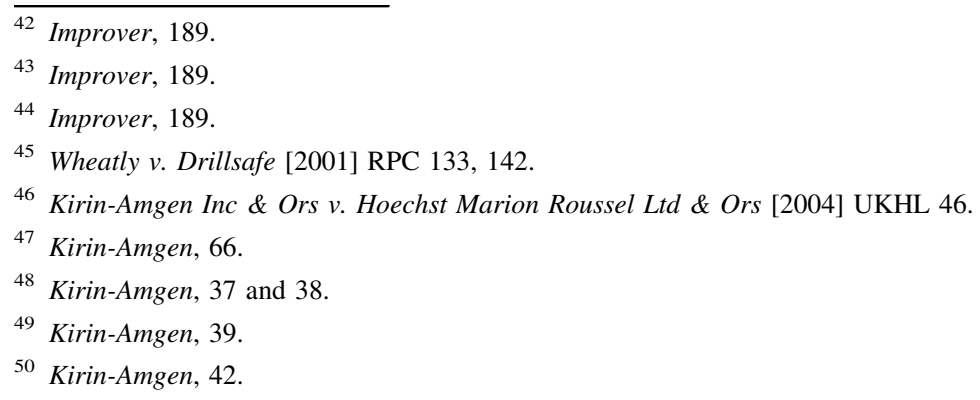


approach to claim construction, this would take any immaterial variation into account. It was seen as an element of construction and therefore within the scope of the claims, rather than outside.

The implementation of the provisions of the EPC and the guidance on claim interpretation had little to no effect in the UK. The Protocol was and is so vague that it can accommodate several approaches to patent claim construction. Courts in the UK had already moved away from a literal approach to claim construction, as seen in Catnic. Further, Lord Hoffmann made it very clear that the practice in the UK regarding equivalents at that time was in line with the EPC and with the Protocol and therefore no changes were necessary.

This was not the case in Germany. In order to implement the provisions of the EPC, a new Patents Act was introduced in 1981. ${ }^{51}$ The new legislation was interpreted by the German Supreme Court in the landmark Formstein decision. ${ }^{52}$ The Supreme Court stated:

The question was not whether the "principle" of the solution to the technical problem by the alleged infringement coincided with that of the patented invention, but whether the average person skilled in the art on the basis of his specialist knowledge could discover from the patent claims, taking the specification and drawings into account, whatever solution was used in the alleged infringement to achieve the same effect. ${ }^{53}$

This is a significant departure from previous practice in Germany. Following Formstein, a quintet of cases was heard by the German Supreme Court, where it was reiterated, again and again, that the claims were now to be "not only a point of departure but the decisive basis for the determination of the scope of protection". 54

One of the most relevant of these cases was the Schneidmesser decision, wherein the court took the guidance from Formstein and rearticulated that guidance into a series of questions which could be used in future cases. The questions, as expressed in English by Peter Meier-Beck, German Supreme Court Judge, are as follows:

Does the modified embodiment solve the problem underlying the invention with means that have objectively the same technical effect? ... If the first question ... has to be answered in the negative, the contested embodiment is outside the scope of protection. Otherwise we have to ask the second question: Was the person skilled in the art, using his specialist knowledge, able to find the modified means at the priority date as having the same effect? ... If the second question ... has to be answered in the negative, the contested embodiment is outside of the scope of protection. Otherwise we have to ask the third question ... Are the considerations that the person skilled in the art had to apply oriented to the technical teaching of the patent claim in such a

\footnotetext{
51 Patentgesetz in der Fassung der Bekanntmachung vom 16. Dezember 1980 (BGBI. 1981 I S. 1), das durch Artikel 2 des Gesetzes vom 4. April 2016 (BGBI. I S. 558) geändert worden ist (German Patents Act).

52 Formstein (Moulded Curbstone) [1991] RPC 597 (In the Federal Supreme Court of Germany).

53 Formstein.

54 Fisher (2008), p. 149.
} 
way that the person skilled in the art took the modified embodiment into account as being an equivalent solution $?^{55}$

As expected, these questions have been compared to the Improver questions on numerous occasions, ${ }^{56}$ and are certainly similar in some respects; however, there are several differences. As elaborated on by Meier-Beck, the first Schneidmesser question is only interested in result of the variant rather than the function, way, and result, as in the first Improver question. ${ }^{57}$ The second questions are both similar, so long as obviousness is interpreted in the same way and according to the EPC. ${ }^{58}$ The third Schneidmesser question asks "whether the considerations of the person skilled in the art are so close to the technical teaching of the patent claim that the variant appears to be an equivalent alternative to an embodiment that realises the wording of the patent claim", thus returning to the elements of the first Improver question relating to the function. ${ }^{59}$ Therefore, although different in certain respects, both the Schneidmesser and the Improver questions involve a value judgment. $^{60}$

This departure from previous practice shows the impact of the legislative provisions in the EPC on the law in Germany. Courts now look at the claims of a patent as a decisive factor in determining the scope of protection. Further, the implementation of questions somewhat similar to those in Improver encourages harmonisation. However, as Matthew Fisher has argued, divergences remain in decisions, possibly due to the philosophical foundations of the patent systems in Germany and the UK - the former being focussed on rewarding the inventor and the latter focussing on boosting innovation. ${ }^{61}$ It could also be argued that these divergences also stem from the differences in the treatment of equivalents by both Contracting Member States.

\subsubsection{Divergences Remain}

Although Art. 69 EPC and the Protocol did change legal practice in certain Member States regarding the determination of the scope of protection of a patent, problems remained. National courts were reaching different outcomes in infringement actions relating to the same patented invention despite interpreting national laws that all implemented the provisions of the EPC.

The most famous example of this is the Improver case. It was argued by the claimant that their European patent, designated in numerous Contracting States, was infringed by the defendant in the UK, Germany and the Netherlands. Actions were brought in each of the relevant national courts.

\footnotetext{
55 Meier-Beck (2005), p. 339.

56 For example: Meier-Beck (2005); and Lord Hoffmann's judgment in Kirin-Amgen.

57 Meier-Beck, p. 343.

58 Meier-Beck, p. 343.

59 Meier-Beck, p. 343.

${ }^{60}$ Meier-Beck, p. 344.

61 Fisher (2008), p. 161.
} 
The Supreme Court of the UK decided that there had been no infringement, whereas courts in Germany, and the Netherlands decided that there had been an infringement. ${ }^{62}$ Despite the courts all referring to the EPC and the Protocol on Interpretation of Art. $69 \mathrm{EPC}$, divergent results emerged. ${ }^{63}$ Improver was not a stand-alone case. Divergent decisions in cases relating to the same patented invention happened again and again. ${ }^{64}$

The issue of equivalents was seen as the point where the UK courts differed to other continental courts. ${ }^{65}$ In Germany and France, for example, a doctrine of equivalents can be used. How it is implemented differs from country to country.

In Germany, for example, the Schneidmesser questions are used to determine if a variant is an equivalent. In France, two means can be considered equivalent if they realise the same function or result, and so the effect or purpose of the variant is the central aspect to be considered when using the French doctrine of equivalents. Furthermore, the French Courts do not look at obviousness nor the intent of the patentee. However, the relevant function must be new, otherwise there will never be infringement by equivalents.

As mentioned, the courts in the UK went to extreme ends to say that there is no doctrine of equivalents in the UK. ${ }^{66}$ The Supreme Court was of the view that a purposive approach to claim construction included taking approximations into account, and therefore, the UK were interpreting claims in line with the EPC advice. $^{67}$

In attempting to promote harmonisation in areas such as claim construction, legislation has not been as successful as intended. As there were two extremely different interpretative methods, a compromise had to be provided for - a meeting in the middle. Although this has changed the practice in Germany, the same cannot be said for the UK.

The vague guidance that was introduced by the Protocol has left room for Contracting Member States to implement the guidance in a way that fits with their

\footnotetext{
${ }^{62}$ UK - Improver Corp v. Remington Consumer Product Ltd [1990] F.S.R 181; Germany - Improver Corp. \& Sicommerce AG v. Remington Products Inc, Case No. 2 U 27/89 (OLG 1991) translated in 24 IIC 838 (1993); Netherlands - translated in 24 IIC p. 832 (1993).

63 Sherman (1991), p. 499.

${ }^{64}$ Luginbuehl (2011), p. 10, has identified numerous cases wherein divergent decisions have arisen: Novartis AG and Cibavision AG v. Johnson \& Johnson Medical Ltd and others 2009/2010 resulted in different decisions regarding the validity in France and the Netherlands on the one hand and the UK and Germany on the other; Document Security Systems v. European Central Bank 2008, where the Dutch courts came to the opposite conclusion of the German and French courts, as well as the Austrian patent office; Pozzoli v. BDMO SA 2007, where the patent was revoked in the UK and France, but valid and infringed in Germany; Angiotech Pharmaceuticals v. Conor Medsystems Inc 2007, which had different outcomes in the UK and the Netherlands; and Muller v. Hilti 1999/2000, where the German court was at odds with the decisions of the courts of Switzerland and France. More recently, this has happened in: Actavis UK Ltd \& Ors v. Eli Lilly \& Company [2014] EWHC 1511 (Pat).

65 For a detailed investigation into the interpretation of patents in Austria, Switzerland, Germany, France, Italy, the Netherlands, Sweden and the UK see Pagenberg and Cornish (2007).

66 That is, until July 2017, as will be discussed below.

67 Kirin-Amgen, 48.
} 
current approach. This is not to say that the Protocol has been ineffective. It is however difficult to ensure that all Contracting Member States interpret patent specifications in the same manner, especially given the differences that exist in national economies and procedures.

Through this example, it can be seen that by reaching a compromise and meeting in the middle, the resulting Protocol was extremely vague. Furthermore, it can be seen that legislative attempts do not always fulfil the intended outcome as not all Contracting Member States changed their practice to align completely with the guidance of the Protocol. It is therefore important to discuss different methods that may promote harmonisation without legislation.

\section{Judicial Cooperation as a Way Forward for Harmonisation Without Legislation}

It is proposed by this article that the way in which the harmonisation of European patent law can be achieved most effectively, and without legislation, is through judicial dialogue and judicial cooperation. In fact, this is already happening quite successfully and is something that should be encouraged and formalised amongst all the institutions of the European patent system.

There are two ways in which this is currently being achieved. First, judges from the various institutions of the European patent system are looking towards one another's decisions. Second, judges are meeting regularly to discuss developments in patent law in general and areas where harmonisation can be achieved.

\subsection{Judicial Decisions}

As mentioned, one of the main concerns regarding the European patent system is the divergence in decisions on the same patent amongst national courts. ${ }^{68}$ Judiciaries have, however, been taking steps in order to reduce the possibility of such divergence. One of the ways this is being done is by looking towards the practice in other courts/Boards.

\subsubsection{National Courts Looking Towards the BoA}

The UK courts have been very active in this regard. The promotion of harmonisation in this manner can be seen in a number of judicial decisions. In Merrell Dow v. Norton it was stated by the UK House of Lords (now Supreme Court) that:

It is ... the duty of the United Kingdom courts to construe section 2 so that, as far as possible, it has the same effect as Article 54 [EPC]. For this purpose, it must have regard for the decisions of the European Patent Office (EPO) on the construction of the EPC. These decisions are not strictly binding upon courts

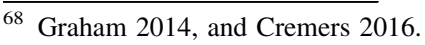


in the United Kingdom but they are great persuasive authority: first, because they are decisions of expert courts (the Boards of Appeal and the Enlarged Board of Appeal of the EPO) involved daily in the administration of the EPC and secondly, because it would be highly undesirable for the provisions of the EPC to be construed differently in the EPO from the way they are interpreted in the national courts of a Contracting State. ${ }^{69}$

Indeed, there is a duty upon the UK to interpret EPC provisions in a way that, as far as possible, has the same effect as the EPC provisions. This duty emanates from the previously mentioned Sec. 130(7) Patents Act 1977, which states as much. This provision has been observed in case law of the UK Court of Appeal, such as Genentech Inc.'s Patent, where it was declared that:

If observance to this provision involves what might appear to be a heretical departure from established practice then this must be laid at the door of the legislator, and taken as disclosing the intention of Parliament to observe the European Patent Convention. ${ }^{70}$

In Merell Dow, the court made it clear that the decisions of the BoA should be considered persuasive authority and considered by the UK courts. This was further emphasised in Biogen v. Medeva, where Lord Hoffmann's judgment realigned the practice of the UK court and the BoA on sufficiency. ${ }^{71}$ Although, in the end, the UK court came to a different final conclusion to that of the Technical BoA, it was said that there was no divergence in the jurisprudence of the courts. ${ }^{72}$

The UK Supreme Court also considered a BoA decision concerning the same patent in great detail in Human Genome Science v. Eli Lilly. ${ }^{73}$ However, the Court also noted that although this practice of looking at the decisions of the BoA should happen, that did not mean that the UK courts had to follow the BoA's reasoning. ${ }^{74}$ It was stated that:

While consistency of approach is important, there has to be room for dialogue between a national court and the EPO (as well as between national courts themselves). Nonetheless, where the Board has adopted a consistent approach to an issue in a number of decisions, it would require very unusual facts to justify a national court not following that approach. ${ }^{75}$

The Supreme Court can be seen to promote a harmonised approach to interpretation, however, also leaving a door open in case the BoA are taking the

\footnotetext{
69 Merrell Dow Pharmaceutical Inc v. Norton \& Co Ltd [1996] RPC 76, 82.

70 Genentech Inc.'s Patent [1989] RPC 147, 197.

71 Biogen Inc. v. Medeva [1996] UKHL 18. However, this was later overturned for product patents in Generics (UK) Ltd v. Lundbeck A/S [2009] UKHL 12.

72 Biogen v. Medeva, [77].

73 Human Genome Sciences Inc v. Eli Lilly [2011] UKSC 51 [42-92], [103-111], [114-115], [117-118], [120-123], [126-129], [134].

74 HGS v. Eli Lilly, [87].

75 HGS v. Eli Lilly, [87].
} 
law "in an inappropriate direction". ${ }^{76}$ By promoting this kind of practice, courts in the UK are encouraged to follow the jurisprudence of the BoA, yet they are not forced to. This allows for continued conversation and dialogue, not to mention national diversity.

When determining whether harmonisation is required, or beneficial, national courts can look at the precedent of their own court, compare it to the alternative approaches or decisions of other courts, and if it is different, the court can decide whether the area in question should be changed to align with how the majority of other countries are interpreting the issue at hand or whether this is an issue of cultural difference. This will be dependent on the viewpoint and culture of that country, and judicial cooperation leaves scope for this type of disagreement. There will always be diversity in the European patent system and that is not something that should be removed.

The scope for disagreement is of significant importance in areas such as morality. Morality is an area on which countries in Europe can differ significantly, for example, what should and should not be patentable. For example, the interpretation of the exception to patentability for the commercial exploitation of inventions resulting from the destruction of human embryos had differed from country to country prior to Court of Justice of the European Union (CJEU) case law.

An exception to patentability is made in these circumstances in all national jurisdictions across Europe given Art. 53 EPC. However, what one country considers to be a human embryo is not the same across Europe. The concept was given an EU-wide definition by the CJEU in Brüstle v. Greenpeace, ${ }^{77}$ however, this was an extremely controversial decision. Following this case law, EU Member States must follow the definition of "human embryo" mandated by the CJEU in Brüstle and updated in $I S C C,{ }^{78}$ despite a majority of countries disagreeing with that definition. In reality, the definition implemented by the CJEU was more restrictive than the understanding of human embryos in many countries. ${ }^{79}$

When it comes issues concerning, for example, morality, human dignity, and ordre public, this scope for divergence needs to exist. Judges in all jurisdictions ought to be able to go against the majority if there is such a reason to do so. It is important that these types of issues remain open to debate and that national diversity remains, given the importance of these topics, the different views involved, and the changing nature of technology.

\subsubsection{National Courts Looking Towards Other National Courts}

This leads to a second aspect of domestic judicial practice that promotes harmonisation and cooperation - to consider the decisions and interpretations of

\footnotetext{
76 HGS v. Eli Lilly, [87].

77 Case C-34/10 Oliver Brüstle v. Greenpeace e.V. ECLI:EU:C:2011:669.

78 Case C-364/13 International Stem Cell Corporation v. Comptroller General of Patents, Designs and Trade Marks (ISCC) ECLI:EU:C:2014:2451.

79 Harmon et al. (2013), p. 92.
} 
other national courts. In Grimme v. Scott, ${ }^{80}$ the UK Court of Appeal emphasised the importance of taking the decisions of other national courts into account, even if no such decisions are presented to the Court by counsel.

The judges in that case decided to do their own research into the question of whether a case of contributory infringement had arisen. It was stated that while conducting this research, an opportunity arose that allowed them to ask judicial colleagues in Germany and the Netherlands if they had had any similar cases on the matter; in the course of that inquiry it was found, to the judges' reported astonishment, that the Dutch courts had previously considered a case concerning Scott's machine. ${ }^{81}$ The court was reportedly astonished because neither party, particularly Grimme, had brought this case to their attention - they went on to say:

Advocates should recognise that where a point of patent law of general importance, such as the construction of a provision which by Treaty (either the EPC or the Community Patent Convention) is to be implemented by states parties to those conventions, has been decided by a court, particularly a higher court, of another member state, the decision matters here. For, despite the fact that there is no common ultimate patent court for Europe, it is of obvious importance to all the countries of the European Patent Union or the parties to the Community Patent Convention, that as far as possible the same legal rules apply across all the countries where the provisions of the Conventions have been implemented. An important decision in one member state may well be of strong persuasive value in all the others, particularly where the judgment contains clear reasoning on the point.

Broadly we think the principle in our courts - and indeed that in the courts of other member states - should be to try to follow the reasoning of an important decision in another country. Only if the court of one state is convinced that the reasoning of a court in another member state is erroneous should it depart from a point that has been authoritatively decided there. Increasingly that has become the practice in a number of countries, particularly in the important patent countries of France, Germany, Holland and England and Wales. Nowadays we refer to each other's decisions with a frequency which would have been hardly imaginable even twenty years ago. And we do try to be consistent where possible.

The Judges of the patent courts of the various countries of Europe have thereby been able to create some degree of uniformity even though the European Commission and the politicians continue to struggle on the long, long road which one day will give Europe a common patent court. ${ }^{82}$

As well as advocates being encouraged to present decisions from other courts on the same issues, the court has also emphasised the importance of taking the decisions of other national courts into consideration. The court again left a door

\footnotetext{
${ }^{80}$ Grimme Maschinenfabrik v. Derek Scott (t/a Scotts Potato Machinery) [2010] EWCA Civ 1110.

81 Grimme v. Scott, [77].

82 Grimme v. Scott, [79-81].
} 
open for divergence in cases where national courts disagree on the reasoning behind a decision, but the main point was that of promoting cooperation and consideration.

This practice was encouraged more recently by the UK Supreme Court in Schütz v. Werit $^{83}$ and Warner-Lambert v. Generics. ${ }^{84}$ In Schütz, the court mentioned in its reasoning that it was relevant to consider four decisions of the German courts. ${ }^{85}$ The reason for doing so was that Germany was also a Contracting State to the EPC. However, it was also said that national courts do have different approaches in relation to many issues and that "while complete consistency of approach may be achieved one day, it is not a feasible or realistic possibility at the moment". ${ }^{86}$

Nevertheless, the court went on to say that "given the existence of the EPC (and the CPC), it is sensible for national courts at least to learn from each other and to seek to move towards, rather than away from, each other's approaches". ${ }^{87}$

In Warner-Lambert, Lord Sumption considered the decisions in France, Germany and Sweden on the same patent stating that "if courts in other jurisdictions have upheld Claim 3, that may serve as a reality check against my own, less favourable conclusions". ${ }^{88} \mathrm{He}$ went on to say that it would be "unfortunate" if divergent decisions arose concerning the same patent; however, after examining other decisions, ultimately decided that none changed his mind given the different questions that were considered. ${ }^{89}$

These are important statements, for it is with this type of interaction that harmonisation will move forward. Although it may be a slow method, given the remaining possibility of disagreement, it appears to be an effective one as instead of waiting for legislation to be debated and entered into force, progress is made on a

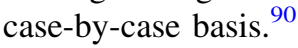

It was noted in the statement above by the court in Grimme v. Scott that the judgments of other jurisdictions are now referred to frequently by courts in England \& Wales, Germany, the Netherlands, and France, relative to 20 years ago. This is indeed the case as this practice of taking other national court jurisprudence into account can also be seen in other jurisdictions.

\subsubsection{Other National Jurisdictions}

In Germany, the Supreme Court has ruled that not only do German national courts have to take the decisions of the BoA into account but went further and stated that they must also consider the decisions of other national courts relating to similar subject matter.

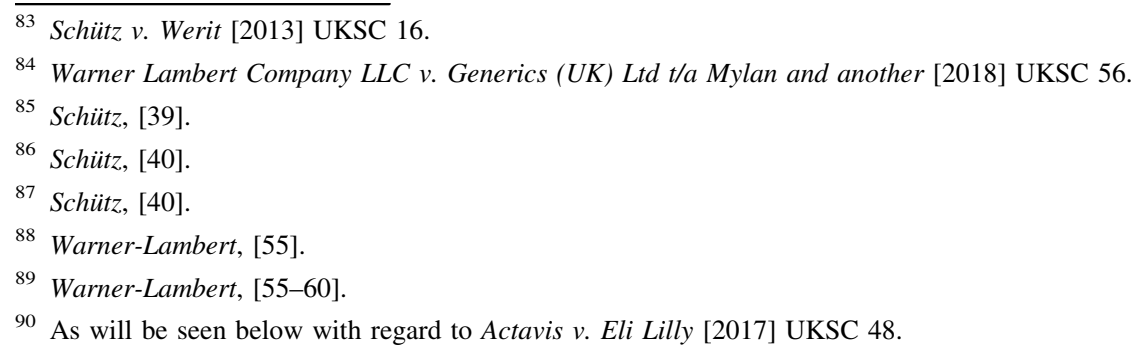


The former requirement was first introduced by the German Supreme Court in the Zahnkranzfräser case. ${ }^{91}$ This decision was subsequently confirmed and expanded in the Walzenformgebungsmaschine case. ${ }^{92}$ In the latter case, the German Supreme Court also stated that the national courts, if diverging from another decision regarding similar issues, must where appropriate, give reasons as to why this divergence is occurring. ${ }^{93}$ However, a caveat was given. The German Supreme Court expressed that the German courts were not bound by these decisions, that any case that deviated from similar judgments was not automatically defective, and this would not necessarily be an appropriate reason for an appeal to the German Supreme Court. ${ }^{94}$

From this judgment, it can be seen that similar guidance is being given to German national courts as in the UK. The doors are left open for possible divergence; however, this should only be in cases where there is an appropriate reason. As the German Supreme Court now requires that these reasons be given, this will assist in discovering where the lines of divergence emerge, and how or whether those lines can be drawn closer together in order to achieve further harmonisation.

In France, proceedings from other courts are increasingly considered. ${ }^{95}$ Searches are conducted as to proceedings taking place in other jurisdictions, and their relevance to the case at hand is examined. Examples include: Mylan v. Astrazeneca, Warner-Lambert v. Sandoz, MVF 3 APS v. S.A.R.L Intelligent Insect Control, Lilly France v. Sanofi-Aventis Deutchland, and Akzo Nobel v. Teva Sante. ${ }^{96}$ However, due to the brevity of French court judgments, it is not always known how relevant other decisions have been in these decisions and others. The relevant cases are cited and often analysed to a certain extent, but it is not clear how much importance is placed on these decisions.

It could be argued, however, that the relevance of other decisions will depend on the similarity of the issues and the facts of the cases, some being more relevant than others depending on the facts. That other proceedings are even mentioned in these decisions, implies that they are at least discussed and considered, even if the same conclusion is not reached.

Although some higher level courts have been encouraging courts at different levels and in different countries to take other patent law decisions into account, it

\footnotetext{
91 Decision of the Bundesgerichtshof, 5 May 1998 (X ZR 57/96) - "Zahnkranzfräser (Gear rim mill)".

92 Decision of the Bundesgerichtshof, 15 April 2010 (Xa ZB 10/09) - "Walzenformgebungsmaschine (Roller-forming-machine)".

93 Luginbuehl, p. 11.

94 An English summary of the Walzenformgebungsmaschine case was provided by: Bardehle Pagenberg, IP Report III [2011] http://www.eplawpatentblog.com/2010/October/Walzenformgebungsmaschine.pdf last accessed 11 July 2018.

95 Including the decisions of the BoA.

96 Paris District Court (Tribunal de Grande Instance de Paris), 3rd chamber 3rd section, 1 July 2016 (15/ 05880), Astrazeneca v. Mylan; Paris District Court (Tribunal de Grande Instance de Paris) 13 October 2015 (15/58725), Warner-Lambert v. Sandoz; Montpellier Court of Appeal (Cour D'Appell de Montpellier), Civil division section 2, 17 September 2015 (13/05047), MVF 3 APS v. Intelligent Insect Control; Paris District Court (Tribunal de Grande Instance de Paris), 23 September 2014 (14/58023), Lilly France v. Sanofi; Paris District Court, 3rd chamber 3rd section, 27 September 2012 (12/13507), Akzo Nobel v. Teva Sante.
} 
has been on the basis of this being a persuasive authority. Taking the argument one step further, it could be argued that judges of the European patent system have a positive duty to cooperate with one another, their respective countries having freely signed up to the EPC.

\subsubsection{BoA Looking Towards National Courts}

The BoA also contribute to the informal harmonisation of the European patent system. For example, to encourage harmonisation, the Enlarged BoA stated in G5/83 that: "[I]t is incumbent upon the European Patent Office, and particularly its Boards of Appeal, to take into consideration the decisions and expressions of opinion of courts and industrial property offices in Contracting States."97

Therefore, it can be seen that the BoA also promote the informal harmonisation of European patent law, and as G5/83 displays, they are willing to consider the reasoning and interpretation of European patent laws from Contracting State courts.

Although this practice appears to be unequivocal, there have been subsequent cases in which the Enlarged BoA has introduced some reservations to this statement; for example, when the national law approach contravenes the intention of the EPC. In G1/13 the Enlarged BoA stated that:

There are of course limits on the extent to which the EPO should follow national law. For example, a provision of national law which purported to confer on a company procedural rights which were contrary to the EPC could not be acknowledged by the EPO. ${ }^{98}$

The Technical BoA have also discussed this issue and have concluded that considerations of harmonisation do not exonerate a board from its duty to act as an independent judicial body with the function of interpreting the EPC and, to decide in the last instance matters relating to patent grant. ${ }^{99}$

Furthermore, the emphasis placed on interpreting the EPC with a view to promoting harmonisation was criticised because not all national laws are harmonised and therefore it would be impossible to decide which interpretation from which national court the BoA ought to follow. ${ }^{100}$ However, through more dialogue, a Board could look at the different interpretations of national courts and decide on a "best practice" approach.

Additionally, national decisions have no binding effect on the BoA. The EPC is the only source of law that is binding on the EPO. Therefore, proceedings before the EPO are decided in accordance with the EPC and even if the reasoning of a national court would lead the EPO to the same conclusion, the Board must first apply the provisions of the EPC and assess the jurisprudence of the BoA in order to make a final decision. ${ }^{101}$ This explains why, in practice, national decisions are still rarely

\footnotetext{
97 G5/83 Second Medical Indication of 5.12.1984, Reasons, 6.

98 G1/13 Admissibility of referral of 25.11.2014, Reasons, 8.

99 T154/04 Estimating sales activity/DUNS LICENSING ASSOCIATES of 15.11.2006, Reasons, 3.

$100 \mathrm{~T} 452 / 91$ of 5.07.1995, Reasons, 5.4.1.

101 T452/91, Reasons, 5.4.1.
} 
explicitly taken into consideration and why, for the BoA, the EPO has the final say in matters relating to the interpretation of the EPC.

\subsubsection{BoA Looking Towards the CJEU}

Albeit less often, the BoA have also considered the jurisprudence of the CJEU, especially when deciding on matters to do with biotechnological inventions (and vice versa). ${ }^{102}$ This was done because the EU Directive on the Protection of Biotechnological Inventions has been incorporated into the Implementing Regulations of the EPC. ${ }^{103}$

This type of practice should be encouraged and extended, especially owing to the generalist overview with which the CJEU operates. ${ }^{104}$ This would ensure that decisions relating to patents do not proceed with a "tunnel-vision", which is a concern when it comes to the operation of the proposed unitary patent package. ${ }^{105}$

\subsubsection{Existing and Attempted Formal Dialogue}

Judicial dialogue already exists formally within the EU between the Member States and the CJEU in matters concerning the protection of biotechnological inventions. Member States are under an obligation to refer questions on the interpretation of this Directive to the CJEU. ${ }^{106}$ This has occurred in a number of cases, ${ }^{107}$ and although the resulting decisions have caused quite a controversy, ${ }^{108}$ the referral is a useful mechanism that could be introduced across the European patent system among national courts and BoA.

In practice, it has already been attempted by the UK court when it "referred" some questions to the Enlarged BoA. ${ }^{109}$ The questions were eventually officially referred to the Enlarged BoA by former EPO President Alison Brimelow. ${ }^{110}$ They were found to be inadmissible, which is unfortunate. ${ }^{111}$

It was a disappointing reference for Lord Justice Jacob, who had made the "referral" in the first place, because the questions referred to the Board did not reflect those that had been originally proposed and the conflicting decisions

\footnotetext{
$\overline{102} \mathrm{G} 2 / 06$ Use of embryos/WARF of 25.11.2008.

103 Biotech Directive; Chapter V, Rule 26(1) Implementing Regulations to the EPC 2000.

104 Schovsbo et al. (2015), p. 271; and Ohly (2013a), p. 264.

105 Schovsbo et al. (2015).

106 As a result of Art. 267 Treaty on the Functioning of the European Union.

107 Brüstle and ISCC.

108 For criticisms on the Brïstle ruling and discussion on the ISCC case, see Burke (2012), p. 346; Parker and England (2012), p. 738; Ohly (2013b), Moore and Wells (2015), p. 258; O'Sullivan (2014), p. 155; Minssen and Nordberg (2015), p. 493; and Nordberg and Minssen (2016), p. 138.

109 Aerotel Ltd. v. Telco Holdings Ltd [2006] EWCA Civ 1371, [75].

110 Jacob (2013), p. 198.

111 G 3/08 Programs for computers of 12.5.2010.
} 
identified by the UK court had not been very well explained; the experiment came to nothing. ${ }^{112}$ If an official line of communication had been opened between Contracting States and the BoA, akin to the CJEU referral mechanism, further harmonisation could have followed.

\subsection{Judicial Meetings and Appointments}

Judicial cooperation is not only seen in the decisions of courts. The second way in which this is occurring is through regular meetings of judges in the field. The EPO is playing a key role in promoting this type of informal harmonisation. They do so in a number of ways including: first, by instigating and organising the biennial European Patent Judge's Symposium and annual European Judges' Forum; second, by having a number of national judges acting as external members of the Enlarged BoA; and third, by arranging judicial internships at the EPO for national court judges.

In 2014, the Judges' Symposium met for the 17th time since its inauguration in 1982. ${ }^{113}$ The reasoning behind the symposium was put forward as a question by Friedrich-Karl Beier in the first of these meetings:

[T]he question necessarily follows, how this harmony of law, which is intended by the legislatures and which has already been achieved at the level of enacted legislation, can now be achieved and safeguarded in judicial practice as well. And does the idea of judicial cooperation within Europe not necessarily follow, of looking more often beyond the limits of one's own jurisdiction, of fortifying the exchange of ideas amongst all of the judges who in future will have to apply the same new European patent law, who will decide the same questions and confront the same problems? ${ }^{114}$

Beier went on to say that European patent law will be shaped by case law, and that "its true contours will emerge only from a multiplicity of individual decisions". ${ }^{115}$ Every two years, judges involved in patent law from all avenues national courts, the BoA, and representatives from the CJEU - come together and discuss developments in patent law in order to continually develop and build up judicial cooperation across Europe. This is an extremely important event for the harmonisation of European patent law.

There are also working sessions wherein potential problems are raised and discussions held on how they might be handled; every session involves presentations from national judges; and since 1994, presentations have been given on certain case studies intended to highlight some difficulties in deciding patent law cases and how these cases could be decided. For example, in 2010 the case of a patent application for a folding attic stairs was discussed. ${ }^{116}$

\footnotetext{
112 Jacob (2013), p. 196.

113 17th European Patent Judges' Symposium, [2015] Supplementary Publication, OJ EPO 5.

114 Beier (1983), pp. 707, 711.

115 Beier, p. 712.

116 15th European Patent Judges' Symposium, [2011] Special Edition, OJ EPO 1, p. 275.
} 
These meetings will presumably continue to take place and if they do, will continue to serve the aim of European cooperation in the patent field by promoting the harmonisation of substantive patent law and procedure by informal means.

Every year, in October, European patent law judges also meet in Venice at the EPO European Judges Forum. Similar to the Symposium, this event gives judges the opportunity to discuss the latest developments in European patent law in their countries and elsewhere.

Harmonisation is further promoted by the appointment of external members to the panel of the Enlarged BoA. ${ }^{117}$ External members are national court judges who can be appointed in cases where the scope of a matter referred extends beyond the internal administration of the EPO. ${ }^{118}$

Along similar lines, judicial internships are also available for national judges of the Contracting States at the BoA. These internships promote equal access to training and provide the opportunity to undertake an intensive course on patentability and procedures at the EPO and the opportunity to "shadow" a member of the Technical BoA. In doing so, they enable national judges to experience the practices of the EPO, which can then be filtered back to their own national courts.

\subsection{Promoting Judicial Cooperation}

The above examples display some of the efforts that have been undertaken by the judiciary/BoA to promote informal harmonisation through judicial dialogue and cooperation. This kind of activity has indeed become more frequent; however, differences remain between courts when it comes to interpretation, but also when it comes to procedures and the evidence brought before each court. Despite these differences, decisions of other national courts, or the decisions of the BoA, can still be considered, and this should be done even more frequently.

It is argued that if judicial cooperation were to happen regularly, the European patent system would become a lot closer and would not be dependent on the implementation of legislation that may or may not improve the situation. Although judicial cooperation may not always lead to convergence, ${ }^{119}$ it is a step in the right direction. To promote judicial cooperation and ensure dialogue between the courts, an online framework of official dialogue could be introduced to assist the judiciary when making decisions on European patent law.

Courts would first have to consider whether the patent in question before them had been or was currently being litigated elsewhere. With an online framework, all cases could be uploaded and machine translated to assist with accessibility. Judges could look at the decisions of other courts or decide to stay proceedings to await the

\footnotetext{
117 Luginbuehl, p. 145.

118 Article 11(5) EPC: The Administrative Council, after consulting the President of the European Patent Office, may also appoint as members of the Enlarged BoA legally qualified members of the national courts or quasi-judicial authorities of the Contracting States, who may continue their judicial activities at the national level.
}

119 Lageza (2012), pp. 115, 125. 
judgment of another court hearing the case. Doing so would likely depend on the level of the court and the experience of the judiciary making the decision.

If the case concerned a patent that had not been litigated previously, the court could investigate its approach to, for example, deciding on the patentability of an invention or sufficiency, and compare it to other courts and the BoA. By doing so, it could learn what the majority of European countries consider when dealing with these issues and decide whether practice could or should be changed in that country as a result.

An open dialogue system could also be introduced, wherein judges could access a confidential online tool linking them to judges in other jurisdictions. Questions and answers could be posted which would eventually become a massive resource for current and new judges. Discussions could be had on a case-by-case basis predecision, rather than once a year at a judge's symposium post-decision. This would hasten the speed by which this informal harmonisation occurs.

In final written decisions, if departing from the status quo, all judges could also be required to expand on why they have departed from the majority view. If this were to happen more frequently, further steps could be taken in analysing how harmonisation could occur in these areas, if it should.

Finally, it should be possible for national courts to refer questions to the Enlarged BoA on the interpretation of provisions of the EPC. By introducing such a mechanism, clear guidance would be given to the Contracting Member State concerned, and this response could also be used by other Contracting Member States in the future.

Certain risks need to be considered, such as that of judicial law making. However, as long as the framework is not taken so far as to introduce new laws, or unfounded interpretations of laws, the judicial cooperation/dialogue model would be of benefit for the harmonisation of the European patent system.

In 2007, following a detailed investigation by a number of authors (including academics, judges and litigators) into the practice of eight countries in Europe with regard to the interpretation of patents, Jochen Pagenberg concluded that amongst all questions discussed "one problem appears as the most difficult to solve, namely how equivalents will be treated in the various jurisdictions all over Europe". ${ }^{120}$ At the time, as elaborated upon above, the UK practice towards (or in this case, against) equivalence stood out from the approaches of other European jurisdictions and the rejection of the doctrine of equivalence was seen as disregarding the balance required by the Protocol on the Interpretation of Art. 69 EPC. ${ }^{121}$ However, recent developments in the UK have gone a long way in providing a solution to this most difficult problem and provides an excellent example as to how judicial cooperation and dialogue can lead to greater harmonisation in practice.

\footnotetext{
120 Pagenberg (2007), p. 281.

121 Pagenberg (2007), p. 281.
} 


\section{Recent Developments - Actavis v. Eli Lilly [2017] UKSC 48}

The most recent and potentially most impactful example of judicial cooperation came in a recent decision of the Supreme Court of the UK and proves how well it can be used as a means to promote harmonisation in the European patent system and shows the impact that it can have.

In July 2017, the interpretation of patent claims was "clarified" once again, changing legal practice in the UK significantly by aligning with its continental neighbours and also arguably with the EPC. Although a recent decision, Actavis $v$. Eli Lilly has had and will continue to have a huge impact on patent law practice. ${ }^{122}$

\subsection{The Case}

The question before the court was whether Eli Lilly's patent on the use of pemetrexed disodium in the manufacture of a medicine for use in combination with vitamin B12 for the treatment of cancer, was infringed (directly and/or indirectly) by Actavis's proposed products that did not use pemetrexed disodium, but pemetrexed diacid, pemetrexed ditromethamine, or pemetrexed dipotassium. ${ }^{123}$ Essentially, did Eli Lilly's patent cover compounds other than pemetrexed disodium?

At first instance, Arnold $\mathrm{J}$ followed the well-established guidance of the UK courts on claim construction, emphasising that equivalents could not be used to extend the scope of protection of a patent in one instance and not the other (infringement and novelty). ${ }^{124} \mathrm{He}$ went on to assess whether or not an infringement had occurred by using the Improver/Protocol questions and decided that Eli Lilly had intended to limit the claims to pemetrexed disodium only, and thus there was no direct infringement. ${ }^{125}$

On appeal, Floyd LJ restated the UK approach to the construction of claims and equivalents:

The fact that English courts do not apply a general doctrine of equivalents to the construction of patent claims does not mean that the existence of equivalents which have no material effect on the way the invention works has no bearing on the proper, purposive interpretation of a patent claim. To the contrary, it has long been the law that such equivalents form part of the

\footnotetext{
122 Actavis v. Eli Lilly [2017] UKSC 48. Besides the point on equivalents, whether equivalents should apply when it comes to the requirement of novelty has been questioned. This was discussed in Generics (UK) Ltd and others v. Yeda Research and Development Company and others [2017] EWHC 2629 (Pat) and was decided that it should not. The doctrine of equivalents has since been discussed by the UK High Court (Patents Court) in: Illumina v. Premaitha [2017] EWHC 2930 (Pat); Fisher \& Paykel v. Resmed [2017] EWHC 2748 (Pat); L'Oréal Société Anonyme v. RN Ventures [2018] EWHC 173 (Pat); Bose Corporation v. Freebit [2018] EWHC 889 (Pat); and Liqwd Inc and Olaplex LLC v. L'Oréal SA [2018] EWHC 1394 (Pat); and by the UK Court of Appeal in: Icescape Limited v. Ice-World International BV \& Ors [2018] EWCA Civ 2219.

123 Actavis v. Eli Lilly [2017] UKSC 48, [4] and [8].

124 Actavis v. Eli Lilly [2014] EWHC 1511 (Pat), [103].

125 Actavis v. Eli Lilly [2014] EWHC 1511 (Pat), [149].
} 
background of facts known to the skilled reader which would affect what he understands the claim to mean. ${ }^{126}$

He said that in interpreting claims like this, English law complies with the Protocol on the Interpretation of Art. 69 EPC, including Art. 2.

Floyd LJ followed the same line of reasoning as Arnold $\mathrm{J}$ at first instance and decided that there had been no direct infringement. ${ }^{127}$

The case was further appealed to the Supreme Court. In one of his final cases as President of the Supreme Court, Lord Neuberger took the opportunity to clarify how claims ought to be interpreted in the UK so as to be in line with the requirements of the EPC and the Protocol on the Interpretation of Art. 69 EPC. In doing so, and despite precedent from the Supreme Court in Kirin-Amgen pointing in the opposite direction, he introduced a doctrine of equivalents into patent scope determination in the UK.

The reasoning behind this ground-breaking decision was to ensure that the UK was in compliance with the Protocol on the Interpretation of Art. 69 EPC. Lord Neuberger stated:

In my view, notwithstanding what Lord Diplock said in Catnic [1982] RPC 183,242 , a problem of infringement is best approached by addressing two issues, each of which is to be considered through the eyes of the notional addressee of the patent in suit, i.e. the person skilled in the relevant art. Those issues are: (i) does the variant infringe any of the claims as a matter of normal interpretation; and, if not, (ii) does the variant nonetheless infringe because it varies from the invention in a way or ways which is or are material? If the answer to either issue is "yes", there is an infringement; otherwise, there is not. Such an approach complies with Art. 2 of the Protocol, as issue (ii) squarely raises the principle of equivalents, but limits its ambit to those variants which contain immaterial variations from the invention. ${ }^{128}$

In expressing infringement as two separate issues, Lord Neuberger asserted that the previous method of claim construction may have been wrong because, using the words of Sir Hugh Laddie, it conflated the issue of interpretation and scope of protection. The reasoning behind this new approach relied on the first issue being a question of interpretation, and the second relating to facts and expert evidence. ${ }^{129}$

By changing the law on claim construction and allowing for a doctrine of equivalents, courts can now consider to what extent the scope of protection of a patent can extend beyond the meaning of the claims in context. ${ }^{130}$ This is completely against the reasoning of the Supreme Court in Kirin-Amgen and thus changes legal practice in this area significantly.

\footnotetext{
126 Actavis v. Eli Lilly [2015] EWCA Civ 555, [45].

127 Actavis v. Eli Lilly [2015] EWCA Civ 555, [80].

128 Actavis v. Eli Lilly [2017] UKSC 48, [54].

129 Actavis v. Eli Lilly [2017] UKSC 48, [54].

${ }^{130}$ Actavis v. Eli Lilly [2017] UKSC 48, [56].
} 
In his decision, Lord Neuberger also revived and reformulated the Improver Protocol questions, into what can now be called the Modified Improver Questions. ${ }^{131}$ Courts can now ask the following questions, which are to be used as a guideline rather than strictly:

(i) Notwithstanding that it is not within the literal meaning of the relevant claim(s) of the patent, does the variant achieve substantially the same result in substantially the same way as the invention, i.e. the inventive concept revealed by the patent?

(ii) Would it be obvious to the person skilled in the art, reading the patent at the priority date, but knowing that the variant achieves substantially the same result as the invention, that it does so in substantially the same way as the invention?

(iii) Would such a reader of the patent have concluded that the patentee nonetheless intended that strict compliance with the literal meaning of the relevant claim(s) of the patent was an essential requirement of the invention?

In order to establish infringement in a case where there is no literal infringement, a patentee would have to establish that the answer to the first two questions was "yes" and that the answer to the third question was "no". 132

Applying these questions to the case at hand, it was decided that the Actavis products directly infringed the Eli Lilly patent because all the Actavis products involved ultimately achieved substantially the same result in substantially the same way as the patented invention ${ }^{133}$; that the person skilled in the art would have appreciated that the products would work in the same way ${ }^{134}$; and that the person skilled in the art would conclude that the patentee did not intend strict compliance with the wording of the claims and would have intended that other pemetrexed salts be included in the scope of protection. ${ }^{135}$

\subsection{The Resulting Implications}

The change to the legal practice in this area has and will have a number of significant consequences. ${ }^{136}$

\footnotetext{
131 Interestingly, in Kirin-Amgen, Lord Hofmann (in the Supreme Court) may not have agreed with the opinion that Neuberger had (relating to the Questions) in Actavis when he made it in in the Court of First Instance in Kirin-Amgen. We now have the reverse where Lord Neuberger has changed the test of Lord Hofmann in favour of his own. This is most apparent in the treatment of the second question where in Kirin-Amgen, Neuberger said that it should be assumed that the person skilled in the art is told that the variant works, which now features in the Modified Improver Questions from Actavis v. Eli Lilly - KirinAmgen v. Transkaryotic Therapies [2002] RPC 2, [26].

132 Actavis v. Eli Lilly [2017] UKSC 48, [66].

133 Actavis v. Eli Lilly [2017] UKSC 48, [68].

134 Actavis v. Eli Lilly [2017] UKSC 48, [69].

135 Actavis v. Eli Lilly [2017] UKSC 48, [74].

136 For discussions on Actavis v. Eli Lilly, see Strath and Jacob (2018), p. 169; Jadeja et al. (2018), p. 564; Johnson (2017), p. 817; and Widera (2018), p. 238.
} 
First, as mentioned, this is a significant change to the legal precedent in the UK. Owing to this decision, practice around drafting patent applications will need to change, and arguments before courts in matters of infringement will have to be carefully considered. Attorneys will have to consider whether to raise an argument of infringement by equivalents, which could imply that their case of literal infringement is weaker (literal in the patent context, not in the textual context).

Second, this judgment brings the UK more into line with other countries in Europe. The Supreme Court investigated how equivalents were used in other countries in its reasoning. ${ }^{137}$ Although in this case, the Court was under an obligation to consider the law from other jurisdictions because the UK court was deciding on patent designations in a number of other countries, it can still be applauded from a harmonisation perspective. By looking at the law from these jurisdictions, parallels and distinctions can be drawn, which can lead to either a more harmonised approach, or a realisation as to why divergence occurs.

Finally, the change to this area of UK law shows how judicial cooperation works at its best. The Supreme Court considered the practice in other jurisdictions as well as the previous practice and precedence in the UK. ${ }^{138}$ The Supreme Court examined the approach of the German, French, Italian, Spanish and Dutch approach towards equivalents, discussed the divergent decisions in Improver, and concluded that there was a difference in approach. ${ }^{139}$ It was ultimately decided that a harmonised approach to equivalents was the way forward. Departing from the previous interpretation of the Supreme Court is unusual, but in this case, it was clearly driven by a desire for harmonisation and to ensure that the UK complies with its commitments to the EPC. ${ }^{140}$

As considered in Pagenberg and Cornish, "greater harmony can only be achieved, if the rules are not only consistent with the Protocol, but also correspond to those of other member countries of the EPC". ${ }^{141}$ Actavis v. Eli Lilly displays how, in practice, this greater harmony can be achieved.

It is yet to be seen how arguments of equivalents will be made before the courts, and whether the UK courts will follow the German or French approach. More likely will be the German approach, owing to the modified Improver questions being closer to the Schneidmesser questions. ${ }^{142}$ However, Lord Neuberger did question the appropriateness of the German courts sometimes requiring the variation not to be inventive in the second question. ${ }^{143}$ Nevertheless, what can be seen is an effort to bring the European patent system closer together by judicial cooperation and explanations as to why one court may not agree with another.

This approach could be further promoted if the unitary patent package enters into force. This proposed system would introduce a new judicial institution - the UPC -

\footnotetext{
${ }_{137}$ Actavis v. Eli Lilly [2017] UKSC 48, [44-52].

138 Actavis v. Eli Lilly [2017] UKSC 48, [44-53].

139 Actavis v. Eli Lilly [2017] UKSC 48, [52].

140 Actavis v. Eli Lilly [2017] UKSC 48, [53-54].

141 Pagenberg (2007), p. 283.

142 Widera (2018).

${ }^{143}$ Actavis v. Eli Lilly [2017] UKSC 48, [64].
} 
into the field of the European patent system. In order for the UPC to be successful, dialogue between it and the current judiciaries and Boards is essential given that not all European countries will participate, and because of the continued existence of current systems. ${ }^{144}$ The UPC will have to decide on how to deal with infringement $^{145}$ and equivalents, and now that most European countries implement a doctrine of equivalents, it would be appropriate for the UPC to do the same.

\section{Conclusion}

In this article, it has been shown that legislative attempts to promote harmonisation by the EU in the European patent system have been unsuccessful, and those implemented by the European Patent Organisation have only assisted to a certain extent. Law making in this area has been seen to take an incredibly long time, which when successful is a compromise, which does not always have the intended impact. The problem of divergence in patent law interpretation and decisions on the same patented product in different courts or BoA continues to occur.

In order to promote harmonisation in a more effective manner, it is argued that this should not solely be done through legislation, but through judicial dialogue and cooperation. Through this means of informal harmonisation, progress can be made case-by-case, rather than waiting for legislation to be agreed upon and entered into force. It was seen that this is already happening to good effect, as displayed through the most recent example of Actavis v. Eli Lilly in the UK Supreme Court. It is proposed by this article that official lines of communication should be opened among all judiciaries and Boards in the European patent system to improve this practice.

It is also suggested that there is a positive duty to cooperate. Contracting Member States have signed up willingly to the EPC and the argument could be made that they are required to take its interpretation into account. Opening official lines of communication would be an important step towards a further harmonised European patent system and would increase legal certainty in this area.

Furthermore, this would also assist the UPC, if introduced. When decisions of other courts are taken into account, best practice can emerge and be used in the unitary patent system. If this were to happen, a trickle-down effect could occur where judges sitting on panels of the UPC would return to their national court and potentially implement the practice of the UPC, thus increasing harmonisation further.

Significantly, this method also leaves room for national diversity, which is of the utmost importance when it comes to areas such as ordre public and morality where countries often differ.

\footnotetext{
144 This point was also highlighted by Margot Frolingher during a keynote presentation at the UP\&UPC Conference at the EPO in Munich on 3 July 2018. Judicial coherence and the UPC is also discussed in detail by Baldan and Van Zimmeren (2015), p. 1529.

145 England (2017), p. 601.
} 
There will always be an element of divergence in the decisions of the European patent system. This is even seen within the same court system, for example between courts of first instance and courts of appeal. However, by implementing such a solution to the current problem, taking all of these factors into account, the entire European patent system can move forward with its goal of harmonisation to the fullest extent and in the most effective manner.

Open Access This article is distributed under the terms of the Creative Commons Attribution 4.0 International License (http://creativecommons.org/licenses/by/4.0/), which permits unrestricted use, distribution, and reproduction in any medium, provided you give appropriate credit to the original author(s) and the source, provide a link to the Creative Commons license, and indicate if changes were made.

\section{References}

Baldan F, Van Zimmeren E (2015) The future role of the unified patent court in safeguarding coherence in the European patent system. Common Market Law Rev 52:1529

Beier F-K (1983) Judicial cooperation in European patent law. IIC 6, pp 707, 711

Burke S (2012) Interpretative clarification of the concept of "human embryo" in the context of the Biotechnology Directive and the implications for patentability: Brüstle v. Greenpeace eV (C-34/10). EIPR 34(5):346

Cremers K, Ernicke M, Gaessler F, Harhoff D, Helmers C, McDonagh L, Schliessler P, van Zeebroeck N (2016) Patent litigation in Europe. Eur J Law Econ. https://doi.org/10.1007/s10657-016-9529-0

Curtin D (1993) The constitutional structure of the union: a Europe of bits and pieces. CML Rev 30:17-67

England P (2017) Common issues of direct and indirect infringement in European and the UPC. JIPLP 12(7):601

Fisher M (2008) New protocol, same old story? Patent claim construction in 2007; looking back with a view to the future. IPQ 2, pp 133, 148

Gordon R, Pascoe T (2016) Re the effect of "Brexit" on the unitary patent regulation and the unified patent court agreement. http://www.bristowsupc.com/assets/files/counsel_s\%20opinion\%20on\% 20effect\%20of\%20brexit\%20on\%20upc,\%2012\%20sept\%202016.pdf. Accessed 20 Aug 2018

Graham SJH, Van Zeebroeck N (2014) Comparing patent litigation across Europe: a first look. Stanf Tech Law Rev 17, pp 655, 708

Harmon SHE, Laurie G, Courtney A (2013) Dignity, plurality and patentability: the unfinished story of Brustle v. Greenpeace. EL Rev 38(1):92

Hilty R, Jaeger T, Lamping M, Ullrich H (2012) The unitary patent package: twelve reasons for concern. Max Planck Institute for intellectual property \& competition law research paper no. 12-12. http:// papers.ssrn.com/sol3/papers.cfm?abstract_id=2169254. Accessed 11 July 2018

Jacob R (2013) The relationship between European and national courts in intellectual property law. In: Ohly A, Pila J (eds) The Europeanization of intellectual property law: towards a European legal methodology. OUP, Oxford, p 198

Jadeja N, Smith-Willis H, Hurdle H (2018) Cast back into the sea of uncertainty - a doctrine of equivalents in UK law? The Supreme Court ruling in Actavis v. Eli Lilly. JIPLP 13(7):564

Johnson P (2017) The (re-)emergence of the doctrine of equivalents. JIPLP 12(10):817

Ladas S (1975) Patents, trademarks and related rights. Harvard University Press, Cambridge

Lageza E (2012) Mapping judicial dialogue across national borders: an exploratory network study of learning from lobbying among European intellectual property judges. Utrecht Law Rev 8(2), pp 115, 125

Luginbuehl S (2011) European patent law: towards a uniform interpretation. Edward Elgar

Majone G (2008) Unity in diversity: European integration and the enlargement process EL Rev 33(4):457

McMahon A (2018) Brexit and the unitary patent package: a further compromised future? Scripted $15(2): 175$

Meier-Beck P (2005) The scope of patent protection - the test for determining equivalence. IIC 36(3):339 
Minssen T, Nordberg A (2015) The evolution of the CJEU's case law on stem cell patents: context, outcome and implications of case C-364/13. International stem cell corporation. Nord Intellect Prop Law Rev 5:493

Moore S, Wells A (2015) Clarification of European law relating to stem cell patents. EIPR 37(4):258

Nordberg A, Minssen T (2016) A 'ray of hope' for European stem cell patents or 'out of the smog into the fog'? An analysis of recent European case law and how it compares to the US. IIC 47:138

O’Sullivan E (2014) International Stem Cell Corp v. Comptroller General of Patents: the debate regarding the definition of the human embryo continues. EIPR 36(3):155

Ohly A (2013a) Concluding remarks: postmodernism and beyond. In: Ohly A, Pila J (eds) The Europeanization of intellectual property law: towards a European legal methodology. OUP, Oxford

Ohly A (2013b) European fundamental rights and intellectual property. In: Ohly A, Pila J (eds) The Europeanization of intellectual property law: towards a European legal methodology. OUP, Oxford

Ohly A, Streinz R (2017) Can the UK stay in the UPC system after Brexit? JIPLP 12(3):245

Pagenberg J (2007) C - conclusion and proposals for greater harmonization. In: Pagenberg J, Cornish W (eds) Interpretation of patents in Europe: application of article 69 EPC. Heymanns

Pagenberg J, Cornish W (eds) (2007) Interpretation of patents in Europe: application of article 69 EPC. Heymanns

Parker S, England P (2012) Where now for stem cell patents? EIPR 7(10):738

Pila J (2013) The European patent: an old and vexing problem. ICLQ 62(4), pp 917, 926

Schovsbo J, Riis T, Petersen CS (2015) The Unified Patent Court: pros and cons of specialization - is there a light at the end of the tunnel (vision)? IIC 46(3):271

Sellens AG (2018) The viability of the unitary patent package after the UK's ratification of the agreement on a unified patent court. IIC 49:136

Sherman B (1991) Patent claim interpretation: the impact of the protocol on interpretation. MLR 54(4):499

Strath J, Jacob R (2018) Actavis v. Lilly: the madness begins. JIPLP 13(3):169

Van Pottelsberghe B (2009) Lost property: the European patent system and why it doesn't work. IX Bruegel Blueprint Series

Wadlow C (2010) Strasbourg, the forgotten patent convention, and the origins of the European patents jurisdiction. IIC 41(2), pp 123, 126

Wadlow C (2013) An historical perspective II: the unified patent court. In: Pila J, Wadlow C (eds) The EU unitary patent system. OUP, Oxford

Walsh K (2019) The unitary patent package, the court of justice of the European Union, and Brexit: (ir)reconcilable? IPQ 2

Widera P (2018) Has pemetrexed revived the doctrine of equivalence? JIPLP 13(3):238

Publisher's Note Springer Nature remains neutral with regard to jurisdictional claims in published maps and institutional affiliations. 